\title{
PENELITIAN ETNOGRAFI TENTANG BUDAYA SEKOLAH DALAM PENDIDIKAN KARAKTER DI SEKOLAH DASAR
}

\author{
Sukadari, Suyata, Shodiq A. Kuntoro \\ Universitas PGRI Yogyakarta, Universitas Negeri Yogyakarta, Universitas Negeri Yogyakarta \\ -, - , sodiq_azis@uny.ac.id
}

\begin{abstract}
Abstrak
Penelitian ini bertujuan mendeskripsikan: (1) pengembangan budaya Sekolah Dasar Negeri (SDN) Kasihan, Bantul dalam pembentukan karakter siswa, (2) pengintegrasian unsur penilaian pendidikan karakter dalam kegiatan sehari-hari di sekolah dasar secara utuh, (3) bentuk kegiatan siswa dalam pelaksanaan pendidikan karakter melalui budaya sekolah, dan (4) hubungan pergaulan antarwarga sekolah setelah mendapatkan pendidikan karakter melalui budaya sekolah.Metode penelitian yang digunakan adalah metode etnografik dengan pendekatan kualitatif, untuk memahami kehidupan masyarakat sekolah berdasarkan sudut pandang masyarakat sekolah yang bersangkutan. Subjek penelitian ini adalah siswa dan warga sekolah SD N Kasihan, Bantul. Sumber data penelitian adalah: (1) sumber tertulis, (2) sumber lisan, (3) artefak, (4) dokumen dan (5) rekaman. Teknik Pengumpulan datanya adalah observasi, wawancara, dan dokumentasi. Analisis data dilakukan sejak, sebelum, selama, dan sesudah penelitian dengan teknik deskriptif kualitatif. Hasil penelitian sebagai berikut. (1) Guru dan kepala sekolah SD N Kasihan Bantul telah memahami budaya sekolah dan pendidikan karakter. (2) Pelaksanaan pendidikan karakter melalui budaya sekolah dalam mengintegrasikan mata pelajaran dengan nilai yang terkandung dalam pendidikan karakter sudah berjalan dengan baik dan signifikan dengan perkembangan perilaku siswa. (3) Kegiatan siswa telah berjalan dengan baik; siswa dapat mengikuti kegiatan intrakurikuler dan ekstrakurikuler sesuai dengan bakat dan minatnya. (4) Hubungan pergaulan antarwarga sekolah berada dalam suasana kondusif dan harmonis.
\end{abstract}

Kata kunci: budaya sekolah, pendidikan karakter, sekolah dasar

\section{AN ETNOGRAPHIC RESEARCH ABOUT THE SCHOOL CULTURE IN THE CHARACTER EDUCATION WITHIN AN ELEMENTARY SCHOOL}

\author{
Sukadari, Suyata, Shodiq A. Kuntoro \\ PGRI Yogyakarta University, Yogyakarta State University, Yogyakarta State University \\ -, -, sodiq_azis@uny.ac.id
}

\begin{abstract}
The research was to describe: (1) the development of Kasihan Bantul State Elementary School culture in the formation of the students' characters; (2) the complete integration of the assessment elements in the character education within the school daily activities; (3) the form of student activities in the implementation of character education through the school culture; and (4) the relationship among the school members after having attained the school culture by means of character education. The research method that the researchers employed was the etnographic method by means of qualitative approach in order to understand the life of the school community based on the school members' point of view. The research subjects were the students and the school members of Kasihan Bantul State Elementary School. The data sources were as follows: (1) written sources; (2) oral sources; (3) artefacts; (4) documentation; and (5) recording. The data analysis had been performed before, during and after the research by means of qualitative-descriptive techniques. The results of the research were as follows: (1) the teachers and the principal of Kasihan Bantul State Elementary School had understood the school culture and the character education; (2) the implementation of character education by means of school culture in integrating the subjects and the values contained in the education character had been well-and-signficantly operated altogether with the improvement of students' behaviors; (3) the students' activities had been well-operated and the students were able to join the intracurricular and extracurricular activities according to their own talent and interest; and (4) the relationship among the school members was in a conducive and harmonius situation.
\end{abstract}

Keyword: school culture, character education, elementary school 



\section{PENDAHULUAN}

Pendidikan karakter memiliki peran yang strategis dalam membentuk pribadi manusia Indonesia yang mempunyai integritas ke-Indonesia-an. Pendidikan karakter dapat dilakukan melalui jalur lembaga pendidikan formal yaitu sekolah, juga melalui jalur informal, yaitu keluarga dan masyarakat. Pendidikan karakter diarahkan pada terbentuknya karakter dan peradaban bangsa yang bermartabat sehingga mampu mencerdaskan bangsa dan sanggup berkompetisi pada tingkat global dengan bangsa-bangsa lain, tanpa kehilangan kepribadian sebagai bangsa Indonesia yang berlandaskan Pancasila dan Undang-Undang Dasar 1945.

Pada Undang-Undang Nomor 20 Tahun 2003 tentang Sistem Pendidikan Nasional (UU Sisdiknas) dirumuskan fungsi dan tujuan pendidikan nasional yang harus digunakan dalam mengembangkan upaya pendidikan di Indonesia. Pasal 3 UU Sisdiknas menyebutkan bahwa pendidikan nasional berfungsi mengembangkan dan membentuk watak serta peradaban bangsa yang bermartabat dalam rangka mencerdaskan kehidupan bangsa. Budaya sekolah berperan untuk mengembangkan potensi peserta didik agar menjadi manusia yang beriman dan bertakwa kepada Tuhan Yang Maha Esa, berakhlak mulia, sehat, berilmu, cakap, kreatif, mandiri, dan menjadi warga negara yang bertanggung jawab. Rumusan tujuan pendidikan nasional tersebut menjadi dasar dalam penanaman nilai budaya dalam rangka membentuk karakter anak didik yang akan menjadi generasi yang berkepribadian Indonesia.

Pendidikan di tingkat sekolah dasar pada hakikatnya merupakan dasar dalam pembentukan karakter anak. Pelaksanaan pendidikan karakter di sekolah dasar tersebut merupakan vitalitas pendidikan yang selama ini telah dilaksanakan. Anak usia sekolah dasar sangat memerlukan perhatian dan penanganan secara serius dalam mengembangkan kepribadian. Hal tersebut perlu dilakukan karena pada usia tersebut merupakan dasar untuk pertumbuhan dan perkembangan karakter anak ke jenjang selanjutnya.

Pendidikan karakter yang dilakukan melalui budaya sekolah dalam satuan pendidikan dasar sangat tepat. Pendidikan karakter pada anak sekolah dasar diharapkan dapat menjadi fondasi yang kuat untuk mengembangkan karakter anak pada usia selanjutnya.

Berkaitan dengan hal tersebut, peran guru dan orang tua serta masyarakat sangat diperlukan, terutama dalam memberikan contoh-contoh perilaku yang baik kepada anak. Guru dan orang tua harus selektif dalam memberikan input, seperti bahan bacaan atau cerita anak. Orang tua juga harus selektif dalam memilih acara televisi di rumah untuk anak karena pengaruh yang diterima pada masa anak-anak tidak mudah dihapus. Dimulai dari masa anak-anak sampai remaja karakter dibentuk secara luas melalui peniruan.

Karakter, menurut filosof kontemporer Michael Novak (Lickona, 1991, p.50) seperti berikut.

Character, observes contemporary philosopher Michael Novak, is "a compatible mix of all those virtues identified by religious traditions, literary stories, the sages, and persons of common sense down through history". No one, as Novak points out, has all the virtues, and everyone has some weaknesses. Persons of much-admired character may differ considerably from one another.

Character so conceived has three interrelated parts: moral knowing, moral feeling, and moral behavior. Good character consists of knowing the good, desiring the good, and doing the good habits of the mind, habits of the heart, and habits of action. All three are necessary for leading a moral life; all three make up moral maturity. When we think about the kind of character we went for our children, it's clear that we want them to be able to judge what is right, care deeply about what is right, and then do what they believe to be right even in the face of pressure from without and temptation from within.

Karakter menurut filosof Yunani Aristoteles, (Lickona, 1991, p.50) seperti berikut.

Good character as the life of right conduct (right conduct) in relation o other persons and in relation to oneself. Aristotle reminds us of what, 
in modern times, we are prone to forget: The virtuous life includes selforiented virtues (such as self-control and moderation) as well as other oriented virtues (such as generosity and compassion), and the kinds of virtue are connected. We need to be in control of our selves-our appetities, our passions to do right by others.

Budaya sekolah merupakan norma perilaku bersama warga sekolah dan konsensus bersama yang terdiri dari seperangkat adat/ tradisi, dan kebiasaan-kebiasaan yang bersifat positif maupun negatif. Perilaku yang dijalankan warga sekolah mengandung unsur norma, ritual, mitos, dan nilai tradisi yang merupakan kepercayaan dasar yang dianut semua warga sekolah dalam berperilaku.

Di dalam budaya sekolah, terdapat substansi yang terkandung di dalamnya, yaitu politik, ekonomi, sosial, intelektual, moral agama, dan estetika. Selain itu, juga terdapat simbol-simbol, persepsi, dan asumsi yang setiap sekolah memiliki pola sendiri yang berbeda dengan sekolah lainnya. Dalam pelaksanaan budaya sekolah, juga terdapat unsur sanksi yang berdasarkan konsensus yang telah disepakati bersama antarwarga sekolah. Budaya sekolah yang ada juga dipengaruhi oleh kehidupan keluarga/masyarakat, tempat siswa hidup di tengah lingkungan tempat mereka tinggal.

Budaya sudah banyak didefinisikan oleh para ahli antropologi. Berikut ini disajikan beberapa definisi budaya menurut para ahli. Menurut Tilman (2002, p.4), “A group's individual and collection ways of thingking, believing, and knowing, which includes their shared, expericuces, consicious ness, skills, values, forms of suppression, social institutions and behaviors.

Young Pai (1990, p.21) berpendapat bahwa budaya seperti berikut.

Culture is most commonly viewed as that patterns of knowledge, skill, behaviors, attitudes and beliefs, as well as material artifact produced by a human society and transmited from one generation to another. Culture is the whole of humanity's intellectual, social, technological, political, economic, moral, religious, and aesthetic accomplishment.
Uteach (2009, p.1) mengatakan, "School culture is the behind the scenes contest that reflects the values, beliefs, norms, traditions, and rituals that build up our time as people in school work to gether."

Pengembangan nilai-nilai dalam pendidikan karakter melalui budaya sekolah mencakup semua kegiatan yang dilakukan kepala sekolah, guru, konselor, tenaga administrasi, dan peserta didik. Budaya sekolah adalah suasana kehidupan sekolah tempat anggota masyarakat sekolah saling berinteraksi. Interaksi yang terjadi meliputi antara peserta didik dengan sesamanya, kepala sekolah dengan guru, guru dengan guru, guru dengan siswa, konselor dengan siswa, pegawai administrasi dengan dengan siswa, guru, dan sesamanya. Interaksi tersebut terikat oleh berbagai aturan, norma, moral, serta etika bersama yang berlaku di suatu sekolah. Kepemimpinan, keteladanan, keramahan, toleransi, kerja keras, disiplin, kepedulian sosial, kepedulian lingkungan, rasa kebangsaan, tanggung jawab, dan rasa memiliki merupakan sebagian dari nilai-nilai yang dikembangkan dalam budaya Sekolah.

Proses pendidikan karakter melibatkan siswa secara aktif dalam semua kegiatan keseharian di sekolah. Dalam kaitan ini, kepala sekolah, guru, dan tenaga kependidikan lain diharapkan mampu menerapkan prinsip Tut Wuri Handayani dalam setiap perilaku yang ditunjukkan peserta didik. Prinsip ini juga menyatakan bahwa proses pendidikan dilakukan dalam suasana belajar yang menyenangkan dan tidak indoktrinatif.

Adapun dalam pengembangan budaya sekolah ada 6 aspek antara lain: (1) budaya moral spiritual, (2) budaya bersih rapi, (3) budaya cinta tanah air, (4) budaya setia kawan, (5) budaya belajar, dan (6) budaya mutu. (Kemdiknas, 2011, p.8). Budaya satuan pendidikan formal tingkat SD memiliki cakupan yang sangat luas, antara lain mencakup kegiatan ritual, harapan, hubungan sosial budaya, aspek demografi, kegiatan kurikuler, kegiatan ekstrakurikuler, proses pengambilan keputusan, kebijakan, maupun interaksi sosial antarkomponen. Interaksi sosial budaya internal kelompok dan antarkelompok terikat oleh berbagai aturan, norma, moral, serta etika bersama yang berlaku di suatu satuan pendidikan sekolah dasar. Jujur, bertanggung jawab, cerdas, kreatif, sehat dan bersih, peduli, dan 
gotong royong merupakan nilai-nilai yang dikembangkan dalam budaya satuan pendidikan formal tersebut. Oleh karena itu, langkah pertama dalam mengaplikasikan pendidikan karakter dalam satuan pendidikan SD adalah menciptakan susunan atau iklim kekeluargaan yang berkarakter yang akan membantu transformasi pendidik, peserta didik, dan tenaga kependidikan serta warga dalam satuan pendidikan SD yang berkarakter. Hal ini termasuk perwujudan visi, misi, dan tujuan yang tepat untuk satuan pendidikan dasar.

Visi dan misi satuan pendidikan dasar, kepemimpinan satuan pendidikan dasar, kebijakan dan manajemen serta partisipasi orang tua dan peserta didik, serta langkah dalam model pembelajaran nilai-nilai karakter akan saling berkontribusi terhadap budaya satuan pendidikan dasar tersebut. Mewujudkan pribadi anak yang berkarakter merupakan ujian yang berat bagi dunia pendidikan karena harus dapat mengubah situasi yang buruk menjadi baik. Ketika anak tidak dekat dengan orangtua, mereka tidak memiliki pengenalan tentang nilai-nilai keluarga. Begitu pula jika di sekolah guru tidak memahami karakter anak, akan berdampak lebih rentan terhadap tekanan dari lingkungan tempat anak berada.

Sekolah dan keluarga merupakan rekanan yang sangat penting karena jika sekolah dapat memperbaiki perilaku siswa ketika di sekolah dan dapat membuktikan bahwa sekolah dapat melakukan itu. Kemungkinan dampak tersebut akan bertahan lama. Sebaliknya, perilaku baik siswa akan berkurang jika nilainilai di sekolah tidak didukung di rumah. Bila di dalam keluarga ada masalah, hal tersebut akan mempengaruhi perkembangan anak di sekolah dalam beberapa hal. Misalnya, kebutuhan-kebutuhan dasar fisik dan emosi seorang anak.

Budaya sekolah dan pendidikan karakter sudah dilakukan oleh peneliti sebelumnya, baik pada Sekolah Dasar, Sekolah Lanjutan Tingkat Pertama (SLTP), maupun Sekolah Lanjutan Tingkat Atas (SLTA). Pada umumnya, perilaku maupun karakter siswa di tingkat lanjutan juga tidak lepas dari hasil dari karakter mereka di Sekolah Dasar (SD). Oleh karena itu, pembinaan karakter di Sekolah Dasar (SD) sangat penting dilakukan. Hal itulah yang mendasari penelitian ini.

Zuchdi dkk. (2011) telah melakukan penditian pendidikan karakter dengan judul
Model Pendidikan Karakter Terintegrasi dalam Pembelajaran dan Pengembangan Budaya Sekolah. Dalam penelitian tersebut disimpulkan bahwa pendidikan karakter dengan pendekatan komprehensif yang terintegrasi dalam pembelajaran bidang studi, disertai dengan pengembangan budaya sekolah dapat meningkatkan karakter murid dengan dijembatani oleh pembentukan KPK (Komite Pendidikan Karakter) atau divisi pendidikan karakter dalam komite sekolah yang sudah ada. Sementara itu, pengembangan budaya sekolah dapat dilakukan dengan cara: menjaga suasana sekolah, meningkatkan perilaku murid, dan mendorong kepada sekolah untuk menjaga dan meningkatkan kepemimpinan. Oleh karena itu, pengembangan budaya sekolah sangat penting agar program pendidikan karakter dapat efektif. Model pendidikan karakter dengan pendekatan komprehensif terintegrasi dalam pembelajaran bidang studi dan pengembangan kultur ini terbukti efektif untuk meningkatkan hasil studi dan aktualisasi nilainilai target yang dikembangkan.

\section{METODE PENELITIAN}

Jenis penelitian ini adalah kualitatif, yang dilaksanakan di lapangan (field research). Menurut Danin (2007, p.6), penelitian kualitatif adalah pendekatan sistematis dan subjektif yang digunakan untuk menjelaskan pengalaman hidup dan memberikan makna atasnya.

Penelitian ini dilakukan dengan menggunakan desain penelitian etnografi. Etnografi merupakan pekerjaan mendeskripsikan suatu kebudayaan. Tujuan utamanya adalah untuk memahami suatu pandangan hidup dari sudut pandang penduduk asli.

Spradley (1979, p.5) mengatakan bahwa inti etnografi adalah upaya untuk memperhatikan makna-makna tindakan dari kejadian yang menimpa orang yang ingin kita pahami. Iskandar (2008, p.208) mengatakan bahwa untuk memahami dan mendeskripsikan budaya dari perspektif ini, seorang peneliti harus memikirkan peristiwa-peristiwa atau fenomena-fenomena dengan cara berpikirnya. Seorang peneliti etnografi harus menerangkan perilaku manusia dengan menguraikan apa yang ia ketahui, yang membuat dirinya mampu berperilaku sesuai dengan perilaku umum dari masyarakat yang diteliti. 
Penelitian ini dilaksanakan di Sekolah Dasar Kasihan yang beralamat di Jl. Bibis Kasihan, Taman Tirto, Kasihan, Bantul, Yogyakarta. Penelitian ini dimulai pada bulan Februari 2013 sampai dengan bulan April 2013.

Pada studi awal, dilakukan studi literatur dan pemilihan setting. Studi literatur dilakukan untuk melacak konstruk teori yang terkait dengan nilai budaya sekolah sebagai bekal untuk mendesain penelitian yang akan dikembangkan lebih lanjut.

Menentukan setting penelitian berkaitan dengan tempat, pelaku, serta kegiatan. Dalam hal ini, kriteria yang dapat dijadikan pegangan seperti yang diajukan Bogdan dan Taylor, (1982, p.57) bahwa tempat yang dipilih harus dapat dipercayai sebagai pengambilan data secara lengkap. Di samping itu, personal yang akan dijadikan subjek penelitian juga harus benar-benar respek dan siap. Berkaitan dengan hal tersebut, Bogdan dan Taylor (1982, p.67) menganjurkan agar seorang peneliti juga menjaga hubungan baik dengan informan dan tidak menjaga jarak dengan informan sehingga tercipta suatu situasi yang wajar.

Sumber data primer dalam penelitian ini adalah siswa, guru, kepala sekolah, sedangkan data sekunder antara lain bersumber pada komite sekolah dan tokoh masyarakat sekitar. Selain itu, juga digunakan dokumen. Data dikumpulkan dengan teknik observasi dan wawancara mendalam (depth interview) dan gabungan keduanya.

Penelitian ini menggunakan metode penelitian kualitatif. Data dalam penelitian ini berupa deskripsi mendalam atas aktivitas subjek berdasarkan perspektif subjek, bukan peneliti. Peneliti melakukan refleksi dengan informan terhadap sikap, ucapan, dan tindakan ritual sehingga terjadi penafsiran intersubjektif. Hasil penafsiran ini kemudian direlasikan dengan kerangka teori yang telah dibangun untuk menemukan jawaban dari permasalahan yang dikaji dalam penelitian ini. Untuk mengungkap permasalahn yang ada, digunakan teknik analisis kualitatif etnografi. Perfomance studies etnografi digunakan sebagai cara untuk menyajikan data secara menyeluruh yang berkait dengan tindakan objek yang teliti.

Proses analisis data dilakukan terusmenerus, baik dilapangan maupun setelah dari lapangan. Analisis dilakukan dengan cara mengatur, mengurutkan, mengelompokkan, memberi kode, dan mengategorikan data. Setelah itu, baru dicari tema budaya yang kemungkinan menjadi fokus penelitian. Fokus penelitian ini diperdalam melalui pengamatan dan wawancara berikutnya. Dalam analisis ini, yang berbicara adalah data dan peneliti tidak melakukan penafsiran. Jika terdapat penafsiran, hal tersebut merupakan hasil pengamatan dan interpretasi informan.

Dalam penelitian ini proses analisis data dilakukan sejak sebelum memasuki lapangan, selama di lapangan dan setelah selesai di lapangan. Sugiyana ((2006, pp.335336), berpendapat "In qualitative research is an ongonging activity that occurs throught out the investigativeprocess rather than after process". Jadi, analisis data kualitatif berlangsung selama proses pengumpulan data, bukan setelah pengumpulan data.

Proses analisis dapat dijelaskan bahwa analisis kualitatif ini terdiri dari tiga alur kegiatan yang terjadi secara bersamaan, yaitu reduksi data (data reduction), penyajian data (data display), dan penarikan kesimpulan/ verifikasi (verification). Komponen analisis data model interaktif ini merupakan upaya berlanjut, berulang, dan terus-menerus. Reduksi data, penyajian data, dan verifikasi sebagai rangkaian kegiatan analisis yang saling susul-menyusul.

Reduksi data merupakan proses pemilihan, pemusatan perhatian, dan transformasi data kasar dari catatan-catatan lapangan. Mereduksi data berarti merangkum, memilih hal-hal pokok, memusatkan perhatian pada yang hal penting, dan mencari tema dan pola. Melalui proses reduksi ini, data dapat disederhanakan, ditransformasikan melalui seleksi, ringkasan ataupun uraian singkat, merangkum, dan seterusnya.

Setelah data direduksi, alur selanjutnya adalah penyajian data (data display) (Miles dan Huberman, 2007, p.17). Mendisplay data merupakan kegiatan mengumpulkan informasi serta menyusunnya sehingga dapat memberikan gambaran pola hubungan antardata. Hal ini memungkinkan peneliti untuk penarikan kesimpulan dan pengambilan tindakan. Dalam penelitian kualitatif, penyajian data dapat disajikan dalam bentuk uraian singkat, gambar, hubungan antarkategori, dan sebagainya. Dalam hal ini, Miles dan Huber- 
man mengemukakan, "The most frequent from of display data for qualitative research data in the past has been narrative tex".

Setelah reduksi data, langkah berikutnya dalam analisis kualitatif adalah penarikan kesimpulan dan verifikasi (Miles dan Huberman, (2000, p.18). Kesimpulan dalam penelitian kualitatif masih bersifat sementara, dan akan sangat tergantung kepada data yang ditemukan. Apabila tidak ditemukan data-data yang mendukung kesimpulan sementara tersebut, maka akan berubah. Tetapi, apabila kemudian ditemukan data-data atau buktibukti yang valid dan konsisten saat peneliti kembali ke lapangan, maka kesimpulan yang dikemukakan menjadi kredibel. Oleh karena itu, kesimpulan dalam penelitian kualitatif mungkin bisa menjawab rumusan masalah yang dirumuskan sejak awal, tetapi mungkin juga tidak. Validitas kesimpulan yang dibuat peneliti bergantung pada data yang ditemukan di lapangan. Hal tersebut sesuai dengan ciri penelitian kualitatif bahwa rumusan masalah itu masih bersifat sementara, dan akan berkembang setelah sampai di lapangan. Kesimpulan dalam penelitian ini, diharapkan dapat menghasilkan temuan baru tentang pola penerapan budaya sekolah dalam pendidikan karakter di sekolah dasar.

\section{HASIL PENELITIAN DAN PEMBAHASAN}

Sejak tahun ajaran 2010/2011, SD N Kasihan Bantul ditunjuk oleh Kemdiknas melalui Dinas Pendidikan Dasar Kabupaten Bantul sebagai sekolah rintisan pendididikan karakter tingkat sekolah dasar yang pertama kali diselenggarakan Kabupaten Bantul. Dalam hal ini, Sekolah Dasar Negeri Kasihan Bantul tidak pernah mengajukan sebagai sekolah rintisan. Pihak Dinas Pendidikan Dasar Kabupaten Bantul yang menunjuk Sekolah Dasar Negeri Kasihan Bantul sebagai sekolah rintisan pendidikan karakter.

Penunjukkan tersebut dilatarbelakangi oleh beberapa alasan seperti berikut. Keunikan Sekolah Dasar Negeri Kasihan Bantul. Artinya, keberadaan sekolah sudah ada sejak zaman Belanda, yaitu tahun 1907. Sekolah tersebut memiliki sejarah yang panjang. Sampai sekarang bangunan-bangunan peninggalan zaman Belanda masih berdiri kokoh dan digunakan untuk ruang kegiatan belajar mengajar. Ditambah lagi tanah yang ditempati ada- lah milik Kraton Yogyakarta (Sultan Ground) sehingga lengkaplah sejarah keberadaan Sekolah Dasar Negeri Kasihan tersebut.

Dalam bidang seni/karawitan, SD N Kasihan Bantul mempunyai prestasi dan predikat yang menonjol sebagai wadah pelestarian budaya adiluhung. SD N Kasihan Bantul mengembangkan seni pedalangan, gamelan Jawa/karawitan, dan permainan tradisional. Hal ini dilakukan sebagai bentuk tanggung jawab moral SD N Kasihan Bantul terhadap pelestarian kebudayaan Jawa.

Pelestarian budaya adiluhung yang dilakukan oleh SD N Kasihan Bantul dianggap mampu menguatkan penerapan nilainilai pendidikan karakter. Budaya adiluhung yang dikembangkan di SD N Kasihan Bantul meliputi seni pedalangan, gending-gending Jawa dengan musik gamelan, juga seni tari, baik tari klasik maupun tari kreasi baru. Seni tari mengandung unsur wirama, wirasa, dan wiraga.

Dalam rangka mengembangkan budaya sekolah, SD N Kasihan mengembangkan budaya malu yang meliputi tujuh hal. Ketujuh budaya malu yang dikembangkan tersebut adalah (1) malu datang terlambat/pulang cepat, (2) malu melihat rekan sibuk melakukan aktivitas, (3) malu karena melanggar peraturan, (4) malu untuk berbuat salah, (5) malu karena belajar tidak berprestasi, (6) malu karena tugas tidak selesai tepat waktu, dan (7) malu karena tidak menjaga kebersihan kantor/sekolah.

Budaya sekolah di SD Kasihan Bantul yang menjadi kekhasan adalah karawitan. Karawitan di sekolah mengaktifkan unsurunsur muatan lokal yang dimiliki sebagai potensi yang harus dimanfaatkan sesuai situasi dan kondisi. Sekolah memiliki prioritas utama bagi tuntutan dasar atas karakter yang ingin diterapkan di lingkungannya.

Sebagai upaya untuk meningkatkan pemahaman tentang budaya sekolah dan pendidikan karakter untuk mewujudkan program yang telah direncanakan pemerintah adalah Kepala Sekolah mengikuti Diklat di pusat yaitu di Bogor dan Jakarta secara periodik untuk memberi bekal yang nanti berperan sebagai manager di sekolahnya. Guru yang dipandang mampu untuk mengimbaskan pemahaman budaya sekolah dan pendidikan karakter ditunjuk oleh kepala sekolah mengikuti diklat yang diprogramkan dari Puskurbuk 
Kemdiknas Pusat Jakarta tetapi pelaksanaannya di Kabupaten Bantul di Dinas Pendidikan Dasar Kabupaten Bantul. Guru dan karyawan yang tidak mengikuti Diklat baik di pusat maupun di daerah mendapatkan sosialisasi tentang pendidikan karakter dan budaya sekolah melalui sosialisasi dari kepala sekolah dan guru yang mengikuti diklat

Pendidikan karakter tetap mengacu pada 18 nilai yang ditetapkan oleh pemerintah untuk diimplementasikan dalam kehidupan sehari-hari di sekolah dan di rumah dalam bentuk perilaku.

Budaya sekolah dapat diklasifikasikan menjadi dua macam, pertama budaya sekolah yang kondusif bagi pengembangan karakter positif siswa, dan kedua, budaya sekolah yang menghambat pengembangan karakter positif siswa. (Kemdiknas (2011, p.7). Secara khusus, tujuan pengembangan budaya sekolah adalah: (1) terbentuknya budaya sekolah yang kondusif bagi pengembangan karakter positif siswa, (2) terbentuk dan terjaganya sistem penyelenggaraan sekolah yang dimiliki lingkungan yang kondusif dan komitmen kuat terhadap upaya bagi penyemaian dan pengembangan karakter positif siswa. Lingkungan yang dimaksud adalah (a) lingkungan fisik dan (b) lingkungan psikologis, sosial, kultural. Kemdiknas (2011, p.10)

Sekolah Dasar Negeri Kasihan dalam melaksanakan pendidikan karakter dari 18 nilai yang ada dilaksanakan secara bertahap, pada hakikatnya nilai karakter yang satu dengan yang lainnya saling terkait atau berhubungan, pemilihan nilai karakter secara bertahap mempunyai alasan yang mendasar nilai yang dipilih diselaraskan dengan keadaan maupun kemampuan sekolah.

Pelaksanaan pendidikan karakter dapat mengintegrasikan nilai karakter yang satu dengan nilai karakter yang lainnya. Misalnya, jika nilai religius dapat diterapkan dengan baik maka nilai yang lain mengikutinya karena anak yang beriman dan bertakwa tentu memiliki sikap yang jujur, disiplin, dan bertanggung jawab.

Pengembangan masing-masing nilai karakter adalah saling mendukung, yang selanjutnya diaplikasikan dalam mata pelajaran. Penanaman nilai karakter dilaksanakan secara bertahap dengan menentukan pilihan nilai karakter. Di samping perangkat kepentingan juga disesuaikan dengan keadaan sekolah. Kepala Sekolah tidak mengambil keputusan sendiri tetapi juga memperhatikan masukan atau usulan dari guru mengingat guru merupakan ujung tombak dalam mengaplikasikan program tersebut.

Berdasarkan pengamatan yang dilakukan di sekolah terlihat bahwa para siswa sudah melaksanakan pendidikan karakter dengan baik. Cara menilai dari hasil pelaksanaan pendidikan karakter yaitu melalui pengamatan yang secara terus menerus. Untuk menilai keberhasilan tentang karakter siswa, guru memberikan nilai dengan beberapa kategori antara lain: Belum Terlihat, yaitu peserta didik belum memperlihatkan tanda-tanda perilaku yang dinyatakan pada indikator, Mulai Terlihat, yaitu sudah memperlihatkan tandatanda perilaku yang dinyatakan pada indikator, Mulai berkembang, yaitu perilaku siswa sudah menunjukkan adanya nilai karakter dan mengalami kemajuan, dan Membudaya, yaitu perilaku yang secara terus menerus menerapkan nilai-nilai karakter secara konsisten.

Penerapan nilai-nilai karakter ini sudah dilakukan sejak tahun pelajaran 2012/2013 di SD N Kasihan Bantul baik dalam pembelajaran di kelas maupun di luar kelas. Dalam program rintisan ini pendekatan yang dipilih dalam kegiatan pembelajaran dilakukan dengan metode PAKEM (Pembelajaran Aktif Kreatif Menyenangkan). Program ini mendukung daya saing dan karakter bangsa yang dilakukan oleh Dinas Pendidikan dan Pusat Kurikulum dengan tujuan untuk mencapai rencana Pembangunan Jangka Menengah Nasional (RPJM) tahun 2010-2014.

Penerapan nilai karakter di SD N Kasihan Bantul dilakukan secara bertahap disesuaikan dengan kebutuhan dan keadaan sekolah. Hasil musyawarah dewan guru dengan kepala sekolah menetapkan nilai karakter tahap satu adalah: Nilai religius, nilai disiplin, nilai jujur, dan nilai peduli lingkungan (kebersihan). Sedangkan tahap dua adalah: nilai bertanggung jawab, nilai kreatif, nilai demokratis, nilai cinta tanah air, Untuk tahap tiga baru direncanakan dan belum dilaksanakan.

Dengan penerapan nilai pendidikan karakter secara bertahap kelihatannya terkesan terpisah-pisah, namun kenyataannya sudah mencakup semua nilai karakter. Sedangkan di SD N Kasihan Bantul kegiatan ekstrakurikuler bertujuan untuk menggali pengetahuan afektif 
dan psikomotorik. Siswa melalui kegiatan minat dan bakat adalah merupakan dasar utama bagi siswa untuk mengikuti kegiatan ini.

Bakat dan minat yang didampingi dengan pembinaan yang profesional benarbenar akan mendukung terwujudnya nilai karakter yang diharapkan. Komunikasi antarwarga sekolah menjadi sangat kondusif setelah pendidikan karakter diimplementasikan di SD N Kasihan Bantul. Semua pihak menyadari betapa pentingnya pendidikan karakter melalui budaya sekolah sehingga perlu didukung agar berjalan dengan baik. Semua menyadari bahwa program ini adalah program bersama dan milik bersama. Untuk menyukseskan program ini pihak sekolah tidak hanya melibatkan guru, karyawan/ pesuruh, atau dewan sekolah dan siswa, tetapi juga melibatkan masyarakat umum, seperti Ketua RT, RW, dukuh, bahkan kepala desa/ lurah untuk bersama-sama mendorong suksesnya program pendidikan karakter bangsa melalui budaya sekolah agar para siswa kelak menjadi insane yang bertakwa, berbudi luhur, berkarakter, dan berbudaya Indonesia.

\section{Pembahasan}

Pemahaman tentang budaya sekolah sangat mempengaruhi perkembangan karakter siswa. Suasana sekolah adalah kualitas lingkungan fisik, psikologis dan lingkungan basis kultural sekolah, baik yang tampak pada lingkungan sekolah secara umum maupun lingkungan dalam kelas. Untuk membekali para siswa agar mampu melakukan filtrasi terhadap nilai-nilai budaya baru yang kurang sesuai dengan masyarakat di lingkungannya maka SD N Kasihan Bantul membekali siswa dengan nilai-nilai budaya tradisional dan Islami (bagi yang beragama Islam) seperti: Tempat Pendidikan Alquran (TPA), shalat berjamaah, dan budaya yang berakar di masyarakat melalui berbagai macam kegiatan ekstrakurikuler, baik di bidang seni tradisional, keagamaan, maupun bidang olahraga. Dengan upaya tersebut anak akan mampu menanamkan budaya sendiri dengan sadar, peduli dan mempertahankannya selaras dengan pendidikan karakter. Sikap ini kalau tidak ditanamkan sejak dini dikhawatirkan akan tergusur oleh budaya asing yang tidak sesuai dengan budaya sendiri. Ada nilai-nilai filosofi kehidupan yang mampu membentuk watak atau karakter siswa. Semua ini tentu sesuai dengan visi maupun misi dari SD Kasihan Bantul yang telah ditetapkan oleh warga sekolah.

Dengan perkembangan teknologi SD N Kasihan Bantul berupaya mengantisipasinya dengan berbagai cara agar para siswa tidak terpengaruh negatif terhadap dampaknya. Upaya tersebut adalah dengan dikembangkannya model pendidikan yang memberikan wawasan atau pengetahuan tentang dampak positif dan negatif dari IPTEK terhadap pengembangan peserta didik di tingkat sekolah. SD N Kasihan Bantul membekali siswa agar memiliki keterampilan dasar menggunakan komputer dan internet. Dari sinilah para siswa mampu mengikuti perkembangan jaman yang modern.

Di lingkungan SD N Kasihan Bantul pemahaman tentang budaya sekolah dan pendidikan karakter telah diupayakan seoptimal mungkin, melalui diklat, sosialisasi, rapat, pertemuan-pertemuan formal maupun nonformal tetapi perlu ditingkatkan lagi dengan harapan mampu menciptakan iklim atau budaya yang kondusif.

Pendidikan yang berbasis kearifan lokal adalah merupakan terminologi yang diciptakan untuk mewujudkan kebijakan desentralisasi pendidikan yang menggunakan kekayaan sosial budaya lokal sebagai modal pengembangan kegiatan pendidikan.

Antara pendidikan dan budaya merupakan dua hal yang tidak terpisahkan. Vygotsky (Kuntoro, 2012, p.7) berpandangan bahwa semua kegiatan manusia termasuk pendidikan mengambil tempat dalam konteks suatu budaya tertentu yang melibatkan banyak tingkat interaksi, saling memberi, menerima keyakinan, nilai, pengetahuan, keterampilan, hubungan terstruktur, dan sistem simbol setiap budaya memiliki alat berupa bahasa dan teknologi yang digunakan sebagai alat berinteraksi dengan lingkungan hidupnya dan dengan itu manusia belajar. Perubahan pada diri individu (kognitif, keterampilan, moral) tidak dapat dipisahkan dari pengaruh keyakinan, nilai, pengetahuan, atau keterampilan yang telah dimiliki oleh budaya masyarakatnya.

Peningkatan pemahaman tentang budaya dan pendidikan karakter dapat disosialisasikan melalui diklat, sarasehan, olahraga, seni, buku, layanan masyarakat, poster, film, atau berbagai media sosialissi lainnya. Tujuan 
sosialissi ini adalah untuk membangun kesadaran yang solid tentang pentingnya budaya dan pendidikan karakter pada seluruh tenaga kependidikan di lingkungan SD $\mathrm{N}$ Kasihan Bantul dan dampaknya para guru benar-benar memahami secara benar tentang pendidikan karakter maupun budaya sekolah yang ada.

Berbagai strategi atau cara untuk mengintegrasikan unsur nilai pendidikan karakter bagi guru dalam kegiatan sehari-hari di sekolah secara komprehensif. Pembelajaran tidak dapat hanya dibebankan untuk materi pelajaran tertentu saja dalam praktik pendidikan karakter pada satuan pendidikan dasar. Karena setiap mata pelajaran yang diajarkan di sekolah dilakukan pengintegrasian dengan mata pelajaran lainnya. Selama ini SD N Kasihan sudah berupaya untuk mengoptimalkan pelaksanaan pengintegrasian khusus nilainilai karakter dengan berbagai cara, namun demikian untuk mewujudkan program yang sudah dibuat agar berhasil, guru senantiasa harus meningkatkan diri utamanya dalam hal pengintegrasian pendidikan karakter dan bekerja sama dengan semua pihak.

Di lingkungan SD N Kasihan Bantul dalam kehidupan sehari-hari perlu diterapkan totalitas pendidikan dengan mengandalkan keteladanan, penciptaan lingkungan, dan pembiasaan melalui berbagai tugas dan kegiatan. Sekolah Dasar Negeri Kasihan Bantul telah memberlakukan budaya budi pekerti dalam pergaulan sehari-hari dan pergaulan siswa dan warga sekolah lainnya sebagai wujud penerapan pendidikan karakter melalui budaya sekolah. Dalam hal ini sekolah sudah menerapkan nilai-nilai karakter (jujur, religius, disiplin, peduli lingkungan) periode 2010/ 2011 dan nilai-nilai karakter (cinta tanah air, kreatif, demokratis, dan tanggung jawab) periode 2011/2012. Diharapkan untuk periode 2012/2013 SD N Kasihan Bantul sudah dapat melaksanakan atau mengimplementasikan 4 nilai karakter tambahan dengan baik (toleransi, rasa ingin tahu, menghargai prestasi, dan gemar membaca).

Keberhasilan program pendidikan karakter melalui budaya sekolah yang kondusif di SD N Kasihan Bantul perlu dimonitor dan dievaluasi. Sudah dilaksanakan monitoring dan evaluasi program oleh (a) kementerian pendidikan nasional melalui Direktorat Pembinaan Sekolah Dasar, (b) Dinas Pendi- dikan Propinsi, dan (c) Dinas Pendidikan Kabupaten, (d). Sekolah.

Untuk evaluasi tingkat sekolah dilakukan oleh tim penilaian tingkat sekolah yang merupakan rangkuman hasil penilaian tingkat kelas. Dengan demikian, dapat diketahui (a) ketercapaian target tingkat sekolah, (b) target apa saja yang belum tercapai dan target yang telah dicarai, (c) faktor-faktor yang menyebabkan target-target sekolah tersebut belum tercapai, (d) kendala-kendala yang dihadapi dalam pelaksanaan kegiatan dan upaya-upaya yang telah dilakukan untuk mengatasi kendala-kendala tersebut untuk tingkat sekolah, dan (e) unsur rencana dan pelaksanaan program yang perlu diperbaiki sehingga diperoleh hasil yang lebih optimal di tingkat sekolah pada waktu berikutnya.

Keberhasilan program pengembangan budaya sekolah dalam pendidikan karakter di SD N Kasihan Bantul adalah sebagai berikut.

Penataan lingkungan fisik sekolah melalui kerja sama yang baik antarwarga sekolah dengan orang tua/wali murid dan kerjasama dengan RT setempat dan juga para pedagang di lingkungan sekolah untuk mewujudkan lingkungan sekolah yang bersih, tapi dan indah.

Pengembangan lingkungan psikologis-sosial-kultural di sekolah dengan adanya pendidikan karakter tampak sekali dampaknya yaitu perilaku sopan santun terhadap sesama dapat dilihat dan dirasakan dalam kehidupan sehari-hari di lingkungan SD N Kasihan Bantul. Sikap dan perilaku saling asih, asah, asuh antarwarga sekolah ini membuktikan adanya kualitas penghayatan dan implementasi adanya pendidikan karakter.

Terwujudnya kebersihan, kerapian dan keindahan antarkelas serta lingkungan sekolah dan tidak lagi ada corat-coret ditembok adalah karena peserta didik disiplin dalam piket dan berperilaku sesuai dengan tata tertib sekolah. Semua ini terwujud juga karena dukungan dari semua warga sekolah.

Terjaganya kerukunan hidup antarwarga sekolah mampu meningkatkan lingkungan sekolah yang damai, tenang dan kondusif. Upacara yang menjadi kegiatan rutin di sekolah juga mampu menumbuhkan cinta tanah air, disiplin serta mampu menghargai jasa para pahlawan, karena dalam upacara disebutkan sila-sila dalam Pancasila, pembacaan pembukaan UUD 1945, menghor- 
mat bendera merah putih, dan doa. Ada yang menarik dalam pelaksanaan upacara saat pembacaan Pancasila, yaitu pada saat pembina upacara membaca teks Pancasila dari sila satu sampai sila kelima cukup hanya menyebutkan nomornya saja dan para siswa mengucapkannya sendiri secara bersama-sama. Dengan demikian peserta didik dan para guru mampu menghafal sila Pancasila dengan benar.

Suasana kekeluargaan di SD N Kasihan Bantul sangat kental. Kebersamaan antarwarga sekolah tampak dalam kehidupan sehari-hari. Guyub rukun, dan rasa solidaritas dapat diwujudkan dalam mencapai tujuan bersama guna meningkatkan sekolah yang berkualitas kepala sekolah, guru, siswa, orang tua, karyawan mampu menciptakan suasana sekolah yang kondusif.

Kesungguhan dalam bersikap dan berperilaku merupakan modal utama dalam rangka meningkatkan kualitas diri dengan bekerja keras, disiplin, bersemangat, profesional, dan menjaga mutu di setiap tahapan proses. Hasil yang dicapai SD N Kasihan Bantul tidak mengecewakan. Sudah banyak prestasi yang diraih SD N Kasihan Bantul.

SDN Kasihan Bantul merupakan sekolah yang mempunyai reputasi baik/bermutu. Untuk itu, siswa dan guru harus membuat kesepakatan untuk menegakkan aturan bersama agar pelaksanaan kegiatan belajar mengajar berjalan sesuai dengan aturan. Budaya malu harus diterapkan, yaitu: (a) malu karena datang terlambat/pulang cepat, (b) malu karena melihat rekan sibuk melakukan aktivitas, (c) malu untuk berbuat salah, (d) malu karena bekerja tidak berprestasi, (e) malu karena tugas tidak selesai tepat waktu, dan (f) malu karena tidak menjaga kebersihan kantor/ sekolah.

\section{SIMPULAN DAN SARAN}

\section{Simpulan}

Pemahaman budaya sekolah dan pendidikan karakter menurut pandangan guru dan kepala sekolah di SD N Kasihan Bantul adalah sebagai berikut: Guru telah memahami budaya sekolah dan pendidikan karakter melalui diklat maupun pengimbasan/sosialisasi dari teman sejawat dan Kepala Sekolah

Pelaksanaan pendidikan karakter melalui budaya sekolah secara garis besar sudah berjalan baik dengan mengintegrasikan dalam mata pelajaran dengan nilai-nilai yang terkandung dalam pendidikan karakter. Pelaksanannya dilakukan secara bertahap sehingga belum bisa dilakukan secara komprehensif.

Pelaksanaan pendidikan karakter melalui budaya sekolah telah berjalan dengan baik. Terbukti para siswa dapat mengikuti kegiatan intra kurikuler maupun ekstra-kurikuler di sekolah sesuai bakat minat atau hobi dari masing-masing siswa. Nilai-nilai pendidikan karakter dapat diaktualisasikan dan budaya sekolah dapat berkembang dengan mengutamakan nilai-nilai tradisi dan kearifan lokal.

\section{Saran}

Berdasarkan hasil penelitian dan simpulan yang telah dipaparkan, makan saran yang dapat diambil pada penelitian ini adalah sebagai berikut. Pertama, semua guru diberi kesempatan yang sama untuk mendapatkan fasilitas tentang pendidikan karakter agar dalam pelaksanakan tugas mengimplementasikan pendidikan karakter benar-benar memahami substansi dari pokok permasalahannya. Dengan demikian makna yang terkandung dalam nilai-nilai pendidikan karakter melalui budaya sekolah tidak menimbulkan penafsiran yang salah dan dampaknya bisa menjadi bias. Dalam pelaksanaannya tentu menjadi tanggungjawab pemerintah. Kedua, pemerintah harus bertanggung jawab terkait adanya dana yang dibutuhkan agar pelaksanaannya dapat optimal dan hasilnya maksimal karena selama ini untuk memenuhi kebutuhan dalam peningkatan implementasi pendidikan karakter menggunakan dana BOSDA yang jumlahnya sangat terbatas.

Ketiga, perlu meningkatkan kerja sama antara sekolah dengan lingkungan sekitar. Keempat, untuk Kepala sekolah selalu mengingatkan guru untuk bersungguh-sungguh, tulus, ikhlas dan sabar dalam mendidik, membimbing serta mengarahkan para peserta didik dalam melaksanakan kegiatan-kegiatan untuk mengimplementasikan nilai-nilai pendidikan karakter sehingga dapat berjalan sesuai program yang telah ditentukan. Kelima, hubungan antarwarga sekolah yang sudah baik harus tetap terjaga keberadaanya. Hal tersebut sangat diperhatikan karena keberhasilan dalam pendidikan karakter harus didorong oleh 
semua pihak yang memiliki satu tujuan untuk mewujudkan visi dan misi SD N Kasihan.

\section{DAFTAR PUSTAKA}

Bogdan, Robert C. \& Biklen, Sari Knopp. (1982). Qualitative research for education: An intoduction to theory and methods. Boston, Massachusetts: Allyn and Bacon.

Danin, Sudarwan, (2007). Menjadi peneliti kualitatif. Bandung : Pustaka Setia

Iskandar, (2008). Metodologi penelitian pendidikan dan sosial. Jakarta: Gaung Persada Press

Kementerian Pendidikan Nasional, (2011). Panduan pembinaan pendidikan $\mathrm{ka}$ rakter melalui pengembangan budaya di sekolah dasar. Jakarta: Kemdiknas.

Kuntoro, Sodiq A. (2012). Konsep pendidikan berbasis kearifan lokal sebagai dasar pembentuk karakter bangsa. Makalah disampaikan pada seminar Nasional dan pendidikan di Universitas Negeri Makasar 11 Juli 2012.

Lickona, Thomas. (1991). Educating for character. New York. Batam Books.

Miles, M. B, \& Huberman, A. Michael. (2000). Analisis data kualitatif. Terjemahan Tjetjep Rohendi Rohidi. Jakarta: UI Press.
Spradley, James P (1979), The etnographic interview. New York : Harcourt Brace Javanovich College Publishers.

Sugiyono. (2006). Metode penelitian pendidikan: Pendekatan kuantitatif, kualitatif dan $R \& J$. Bandung: Alfabeta.

Tilman, L.C. (2002). Culturally sensitive research approaches: An African American Perspectif American Educational Research Association 31, 3-12.

Tim Peneliti PPs UNY. (2003). Pedoman pengembangan budaya sekolah. Kerja sama Direktorat Dikmenum Depdiknas-PPs UNY.

Undang-undang Republik Indonesia Nomor 14 Tahun 2005 Tentang Guru dan dosen.

Uteach. (2009). Understanding school culture. Artikel Natural Dapat diakses melalui http/uteach utexas. Edu/90/ wings/mentor.Development/school.culture.

Young Pay. (1990). Cultural foundation of education. Marietta: Merrill Publishing Company.

Zuchdi, Darmiyati dkk, (2011).Model pendidikan karakter terintegrasi. Yogyakarta: UNY Press 